\title{
Public Private Partnership Model in Improving Quality of Hospital Services
}

\author{
${ }^{1}$ Woro Utari, ${ }^{2}$ Hidayat, ${ }^{3}$ Andi Iswoyo \\ ${ }^{123}$ University Wijaya Putra
}

\begin{abstract}
This study aims to identify and analyze the role of the private sector in improving the quality of hospital services.Besides, the study also aims to build a model of private partnerships and government in improving the quality of hospital services. The government's success in improving the quality of services at the hospital depends on all parties, including the business community, private sector and civil society. Private sector role in improving the quality of hospital services in East Java is still relatively less, this is indicated by the results of interviews with hospital administrators were selected as sample.The results of another study showed that the model of partnership that is beneficial to the government and the private sector is a model of partnership with the OCA.Besides, the results showed that there needs to be government policy with regard to enhancing the quality of hospital services through public-private partnerships. One of the government's policy with regard to improving the quality of hospital services is to change the management model of hospitals into Public Service Agency. With a management model Public Service Board is expected to improve the quality of service.
\end{abstract}

Keyword: Public Private, Partnership, Quality

\section{Introduction}

The success of the National Health Insurance program is not just a government responsibility, but it is the responsibility of all parties including the community and the business world. It is therefore necessary synergy strong inter government and private sectors (including investors) and society (civil society) to complement and encourage the fulfillment of one of them through a partnership mechanisms or public private partnership (PPP) and the fulfillment of corporate social responsibility (corporate social responsibility / CSR) which is now the duty of every company. (Journal of Health, 2013).

Related to the issue of public response to the quality of health care, it can be understood that the assessment of the merits of health care tends to be determined by the perception, both objectively and subjectively by users of the service (Yaumi, 2004). There are various reasons for not Settlement of health services both medical and non-medical such as limited budget, the hospital administrative procedures, limitations of medicine, medical personnel lack of human resources, physical infrastructure hospitals etc. (Trisnantoro, 2005; 47). A fundamental problem in health care in the hospital is less maximal hospital services which caused limited medical and non medical personnel, lack of infrastructure and availability of drugs. Besides also limited partnerships undertaken by the government with the private sector, especially with a large hospital. (Wihartoseno and Medi Kuswedi, 2010). Besides, the other issue that drives this research is the low private sector's role in efforts to improve the quality of hospital services with particular regard to the provision of medical equipment facilities.As in the above description in mind that the government's efforts in improving the quality of hospital services can not be separated from the role of the private sector. Therefore, there should be the role of the private sector in improving the quality of hospital services and the provision of hospital equipment in the form of partnership. Besides, the government needs to create a policy with regard to the implementation of the partnership and create standard rules of the policy..The problem in this research is how the private sector's role in providing health services, the partnership model that may be implemented in an effort to improve the quality of service as well as the obstacles faced by the government and the private sector in implementing the partnership. Besides, other issues are looking for an alternative government policy thirsty implemented in an effort to meraslisasi public-private partnerships in order to raise the quality of hospital services.The purpose of this study was to determine and analyze the role of the private sector in providing health services, another goal of this research is to create a partnership model as well as the obstacles faced by the government and the private sector in the running of partnerships. Other research objectives is to find alternative policies that might be done by the government for realizing the goal of the government in improving the quality of hospital services in East Java.

\section{Partnership Services, Government Policy}

Partnership is a form of alliance between two or more parties who form a bond of cooperation based on agreement and mutual interests in order to improve the capabilities and capacity of the sector in a specific area 
or a specific purpose so that it can obtain better results (Sulistiania, 2004: 129-130) Partnerships can also be interpreted as a form or joint venture of public and private sector to achieve common goals (Dikson Jonah, 2008). Public-Private Partnerships (Public Private Partnership) is a partnership model based on a framework of the best providers (Best Sourcing). With Best Sourcing framework, the government can encourage the private sector to be involved in providing certain public services which it will further improve the efficiency and effectiveness of services (value for money) and provides a win-win solution for both the government and private parties.Potential benefits to be gained government in partnership, among others (Sciulli, 1997; Hughes, 1998; Hale, 2004): cost savings (Cost Savings), reduces the risk (Risk Sharing) improve the level of service and quality of service, improve budget efficiency, increase revenue, encourage private sector growth, boost regional economic growth

\section{Service}

Quality of service is a total experience that can only be evaluated by the patient (Zeithamal et al, 1988). While the quality of services is the expected level of excellence and control over the level of excellence to meet the patient's wishes (Lovelock, 1988).Quality of service is good in the long term will generate loyalty patient, it will certainly reduce the cost of developing the profitability and market share (China, 1990; Daniel, 1992; Synchan, 1990). The quality of public service excellence is determined by the bureaucracy. Bureaucratic institutions at this level are required to have the ability and skills, especially regarding services in the fields of education, health, social services, security and order. Efforts to improve the bureaucracy is linked to the role of government, patron-client relationships, and professionals. In addition, forge bureaucratic skill requires great leadership commitment because it requires the synergy of existing resources.

Policy

Public policy is a policy made by the government as policy maker to achieve certain goals. Anderson, 2000 (in Nurcholis, 2005)

\section{Research Methodology}

This research type is descriptive quantitative research, ie to explain the phenomenon that is performed using data taken through informant interviews with selected. Data was collected using a questionnaire and interview guide addressed to the heads of government hospitals. Furthermore, the data that have been collected in the analysis using descriptive analysis and strategy with SWOT analysis.

\section{Results and Discussion}

Based on the survey results revealed that the quality of services the District General Hospital in East Java is relatively small, as well as interviews with hospital administrators. the results showed there are some private companies that have been cooperating with the government in this case the local general hospitals, including the College of both the University (Faculty of Medicine), the Academy of Midwifery (Akbid) and the College of Health Sciences (Stikes) from various institutes of higher learning public and private. PT. Roda Utama, PT. Jamsostek, PT. Dharmawangsa Medical Supplier; Optical Family; PT. Bank of East Java, PT. Demka. Based on the scope of government and private partnerships can be divided into a partnership in education include apprenticeships, training, seminars and study lajut. Partnership with others in the field of procurement of medical equipment or medical equipment.

This is due to the unclear model of partnership that exists between the government and private sectors. There are a variety of private sector role in improving the quality of service are:

1. Improve the quality and effectiveness of health services eg ISO certification One role of the private sector in improving and providing quality hospital services is to improve the quality and effectiveness lyanan through ISO certification, meaning that with the ISO certification indicates that the quality of the service has been good. Public expectations every hospitals already have ISO certification thus demonstrating the standardization of the quality of basic services.

2. Partners in the government's work to improve the quality of service example: KSO medical devices, supporting health promotion activities, etc.

Improving the quality of hospital services is not only the responsibility of the government but it is the responsibility of all stakeholders including the private sector. Therefore, the private sector must participate in improving and providing quality hospital services. There are many ways to play a role in improving the quality of service, including the provision of medical devices.

As we know that the budget available to hospitals for each hospital is very limited, therefore it is sometimes insufficient to hold medical equipment which are expensive. This is an obstacle for hospitals to improve quality of service. In this condition, the role of the private sector is needed by the government. As was done by the private sector to some hospitals by providing medical equipment that is not provided by the hospital and then perform operational cooperation. The operational cooperation with regard to the results. 
Technical implementation of technical cooperation when viewed globally is enough synergy by using methods are quite effective according to the procedure so that when fully panned for its implementation will result in something that can and is maximal and satisfy all parties.

3. Conducting a study on health issues so as to provide input in the development of appropriate service quality problems encountered (evidence based).

In an effort to improve the quality of service, it is necessary to survey or study of health problems. It is necessary to know how the public perception of the quality of hospital services. If the perception is given to the user indicate negative things the government could do the repair and improvement efforts. This study is not only related to the quality of services but also covers other issues. For example the problem of funding, availability of goods, availability of doctors etc.

4. Support in financing activities eg health services: Health insurance

Private sector role in improving the quality of service can be done with support in funding health care (insurance). With the insurance for the means will ensure the funding of health care for patients. The hospital will feel comfortable when existing patients covered in the insurance, it provides a guarantee of payment. Patients who have relatively more orderly in the insurance payment, especially private insurance.

With insurance, hospitals as health care providers, while insurance as well as insurance membership budget.

5. The government partners in providing health services The role of private sector in an effort to improve or provide health care services including the development of private hospitals, clinics, etc. It is expected by the increasing number of private hospitals will improve health services in general, with a record of the existence of private hospitals have to follow the rules, for example for the establishment of private hospitals must meet the rules for personnel such as the number of physicians minimum that must be owned by the new hospital, the number of doctors specialists who should be there, the building area of the minimum that must be available to establish new hospitals and others. These regulations must be stressed because when the new hospital did not have the appropriate requisite doctor will have an impact on physician services in government hospitals (hospitals). This is due to the private hospitals still need to employ doctors in government hospitals, so sometimes at the government hospital physician shortages. The problems that arise actually is a shortage of doctors

6. Motivator for improved healthcare through increasing the role of local community organizations such as youth clubs, religious organizations (Aisiyah, Fatayat NU, etc.).

\section{The conceptual framework model}

Contract Services - Operations and Maintenance General government publicly perform the contract / agreement with the private sector to provide and / or maintain services or specific services. Based on the selection and maintenance operations that have been given to the private sector, the public partner retains ownership and all public facilities or systems management. - Operations, Maintenance, Management Partner public contact cooperation with the private sector to operate, maintain, and manage the facility or system to improve service. Under the contract / agreement, the public partner retains ownership but private companies may invest their capital in the facility or system. Any private very cautious in estimating the investment on any cooperation with an efficient operational system and savings during the contract period.One model of partnership that can be offered to governments and the private sector with regard to efforts to improve the quality of service is the model of BOT (Built Operation Transfer), provision of medical equipment in both quantity and quality through cooperation with MoU (Memory of Understanding).

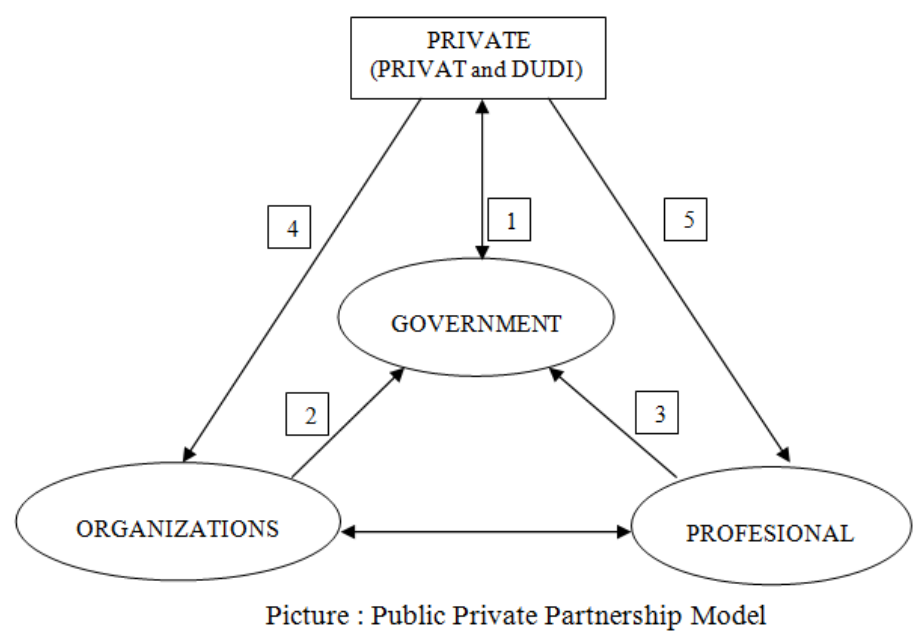




\section{Government Strategy for Improving the Quality of Service}

The success in increasing the quality of service is not only the responsibility of the government alone, but is the responsibility of both the government, private sector, community organizations and society in general. There are several strategies undertaken by the government in an effort to improve the quality of service, including through cooperation with the private sector. Private parties are parties who have the funds to improve the quality of service. As an arm of government, the hospital has the power in an effort to provide health services to the community. The power which is owned by the government (hospital) is to have its own building, the management of the local government budget, the budget needs fulfilled by the government, this condition makes the existence of the hospital from time to time at the safety position. Over time, public hospitals were growing up with private hospitals, and this is one of them because of limited budgets. Moreover, if in one district / city there are two public hospitals, as a result of local budgets should be divided into two, it will have an impact on the narrower the location of the funds for each hospital. The impact of further efforts to improve the quality of service is getting short of expectations.

Efforts to improve the quality of service can not be separated from the availability of medical equipment in hospitals. While there is still a regional hospital that do not have certain medical equipment that should be owned, besides that there are also hospitals that already have the equipment, but the number is very limited. One of the weaknesses of the management of public hospitals were there at the service procedure is still considered complicated by the user. Therefore, there needs to be improvement in the service procedures. In addition, the weakness of which is owned by the hospital in providing services there on the limitations of human resources both medical and non-medical personnel. This is due to many private hospitals are using doctors from government hospitals, so the impact on the unpreparedness of doctors when needed.

Given the number of people very much and in need of health services, the hospital has the opportunity to improve the quality of its services. Besides, public awareness of the importance of health began to be felt by the government, this is evidenced by the increasing number of people who go to the hospital. These opportunities will not be achieved if there is no effort to improve the quality of services in both capacity and quality. Efforts to improve the quality of service is a challenge for the government (hospital), this is due to public image of public hospitals were less good. The low quality of hospital service areas have an impact on the emergence of private hospitals, both managed by private individuals and managed by community organizations. Therefore it is a big challenge for the government to improve the quality of its services in order to compete with private hospitals.

One of the efforts undertaken by the government in improving the quality of hospital services is a partnership with the private sector. There are many partnerships that can be done between the government and the private sector, the partnership associated circuitry and enhancing the provision of medical equipment and health financing.

\section{Government Policies Related to Partnerships}

One of the government's efforts in improving the quality of service is a partnership with the private sector. There are a variety of partnerships that can be done by the government and private sectors, including partnerships supplying medical equipment, research and development. Specialized in medical equipment supply partnership, there needs to be a clear agreement with regard to the results. There are several principles of partnership that must be met by the government and private sectors are: equality (equity) in which each party must feel that partnering sat together and stand as tall. Openness (Transparency) partnership can be done if there is openness between the two parties and the third is mutual (mutual benefit). Therefore, one way that the private sector is willing to do a partnership government should require hospitals became BLU order to become a hospital that profit. This policy should be enshrined in legislation that is clear and unequivocal.

\section{Reference}

[1]. Churchill and Suprenant, 1982; Oliver and De Sarbo, 1988; Spreng and Olshavsky 1993, International Journal of Bank Marketing, 16/2, 1998, p. 53)

[2]. China, 1990; Daniel, 1992; Synchan, 1990, Implication of Loyalty Program Membership and Service Experiences for customer Retention Value, Journal of Academy of Marketing Science.

[3]. Don and Taylor, 1982, Measuring service quality : a reexamination and extension, Journal of Marketing Vol. 56, July, pp. 55-68.

[4]. Dikson Jonah, 2008, Partnership on urban poverty alleviation programs" legality journal Vol 3 no 2

[5]. Evans, 1999. Customer Relationship Management : Creating The Customer-centric

[6]. Financial Services Organization. Lafferty Publications, Dublin Fitzsimmons

[7]. $\quad$ Fandy Tjiptono, "Marketing Management Services ", Publisher andi Offset,Yogyakarta, 2001

[8]. Gershon, Richard, 1993. Measuring Customer Satisfaction. Crisp Publication, Inc

[9]. Ivancevich, 2002, Building customer loyalty, Business skills express series, Irwin professional publishing \& the mirrors press.

[10]. J.A. and Fitzsimmons. 2001. Service Management : Operations, Strategy, and InformationTechnology.TheMcGraw-Hill, Singapore

[11]. Kotler Philip, 2000, "Marketing Management, the concept and the theory" Publisher Ghalia Indonesia, Jakarta

[12]. Mahmudi. 2007 " Partnership the Regional Government and the effectiveness of Public Services" Journal Synergy, Business analysis and Management Vol 9 No.1. 
[13]. Sulistiani A, 2004, "Partnership and Empowerment models" styles, Media, Yogyakarta

[14]. Sulistiani A, 2004, "Partnership and Empowerment models" styles, Media, Yogyakarta.

[15]. Trisnantoro, Laksono, 2005, understand the use of economic science in the management of the Hospital, Gadjah Mada University Press, Yogyakarta

[16]. Thoha (2009, Flagship bureaucracy in the Era of globalisation, PD Batang Gadis, Jakarta

[17]. Trisnantoro, Laksono, 2005, understand the use of economic science in the management of the Hospital,Gadjah Mada University Press, Yogyakarta

[18]. Thoha (2009, Flagship bureaucracy in the Era of globalisation, PD Batang Gadis, Jakarta

[19]. Woro Utari, 2008, "Analysis of macro economic fundamentals and Pengarunya against the acceptance of the Value Added Tax", Journals Neobis

[20]. Woro Utari, 2013, "Analysis of the quality of the service and its impact on the patient Satisfaction Hospital Nasrul Ummah Lamongan", journals Neo Bis, ISSN 1978- 5275, Vol 7 No 1.

[21]. Woro Utari, 2011, "Marketing Analysis Mixed and its influence to the increased sales volume on PT Combiphar Surabaya". The Journal of economic partners and Business Management- ISSN 2087-1090, Vol 2 Number 2

[22]. Woro Utari, 2010, "Customer Satisfaction Model as Moderating variables to increase customer loyalty on the participating airlines" Journal Economic Partners and Business Management- ISSN 2087-1090, Vol 1 Number 2

[23]. Woro Utari, 2009, "The Influence of the dimension of the quality of service to the Customer Satisfaction Fast Credit Secure (KCA) on Perum Pegadaian in Surabaya", Economic journal Science and education; Swastika, ISSI 2085-5680, Vol 2 Number 1

[24]. Yami, 2004, Quality Management Products and Services, Ekonesia, Yogyakarta

[25]. Zeithaml et al, 1985, a Conceptual Model of Service and Its IOmplication Qualilty for Feature Research, The Journal of Marketing, Vol 49.

[26]. Zeithamal et al, 1988, Serqual a Multiple Item scale installation design for Measuring Consumer Perceptiop of Service Quality, Journal Retailing

[27]. Zeithamal, 2000, Consumer Quality, Profitability and the Economics worth of Customer :What We know and whan we need to learn, JKournal of the Academy of Marketing Scienceami, 2004, Quality Management Products andServices,Ekonesia, Yogyakarta

[28]. Zeithaml et al, 1985, a Conceptual Model of Service and Its IOmplication Qualilty for Feature Research, The Journal of Marketing, Vol 49.

[29]. Zeithamal et al, 1988, Serqual a Multiple Item scale installation design for MeasuringConsumer Perceptiop of Service Quality, Journal Retailing

[30]. Zeithamal, 2000, Consumer Quality, Profitability and the Economics worth of Customer :What We know and whan we need to learn, JKournal of the Academy of Marketing Science 